\title{
O PRINCÍPIO RESPONSABILIDADE E A EDUCAÇÃO: APORTES FREIRIANOS PARA UMA COMPREENSÁO ECOPEDAGÓGICA DA HEURÍSTICA DO TEMOR EM HANS JONAS
}

\author{
THE RESPONSIBILITY PRINCIPLE AND EDUCATION: FREIREAN \\ CONTRIBUTIONS TO A PEDAGOGICAL UNDERSTANDING OF THE \\ HEURISTIC OF FEAR IN HANS JONAS
}

\begin{abstract}
Juliano Peroza
Doutor em Educação pela Pontifícia Universidade Católica do Paraná - PUCPR, Paraná, (Brasil). Professor de Filosofia no Instituto Federal de Educação, Ciência e Tecnologia do Paraná - IFPR. ORCID: https://orcid.org/oooo-000I-5I9I-5I6I juperoza@gmail.com
\end{abstract}

Resumo: Este artigo apresenta uma reflexão sobre a ética da responsabilidade do filósofo alemão Hans Jonas, especificamente a partir da sua concepção de heurística do temor em diálogo com o pensamento de Paulo Freire. A reflexão objetiva compreender a expressão heurística do temor a fim de interpretar a contribuição do seu significado com algumas proposiçóes pedagógicas para contribuir com as discussōes sobre ética, responsabilidade e a ação educativa. A metodologia da abordagem é de cunho bibliográfico e hermenêutico. Discute-se que a educação pode assumir essa tarefa de produçáo intencional da representação dessa imagem do temor que ainda não foi experimentado, de modo que a mesma traduza em aspectos político-pedagógicos seus reais propósitos de problematizar conjunturas e conscientizar a partilha global da responsabilidade. Propóe-se, com base em Paulo Freire, uma educação conscientizadora, uma ecopedagogia para a cidadania planetária.

Palavras-chave: Conscientização; Ecopedagogia; Educação; Ética da Responsabilidade; Heurística do Temor.

AbSTRACT: This paper aims to present a reflection on the ethics of responsibility of the German philosopher Hans Jonas, more specifically from his conception of heuristics of fear in consonance with Paulo Freire's thinking. The reflection has as a goal to understand the heuristic expression of fear in order to interpret the contribution of its meaning with some pedagogical propositions to contribute to discussions about ethics, responsibility and educational action. The methodology of the approach is basically of bibliographical and hermeneutic character. It is argued that education can assume this task of intentional production of the image of fear that has not yet been experienced, so it can translate into political-pedagogical aspects its real purposes to problematize conjunctures and to bring 
awareness to the global share of responsibility. It is proposed, based on Paulo Freire, a conscientious education, a ecopedagogy for a planetary citizenship.

KEYwORDs: Consciousness; Ecopedagogy; Education; Ethics of Responsibility; Heuristic of Fear.

\section{Introdução}

Na história do pensamento ocidental muito já foi debatido, no âmbito filosófico e educacional, sobre as dimensões da ética e suas implicaçôes no que se refere à fundamentação axiológica dos valores para a vida em comunidade. De tempos em tempos surgem novos temas que lançam luzes sobre esse debate e provocam novamente o exercício da reflexão criteriosa sobre os fundamentos da moral, as possibilidades de encontrar princípios válidos universalmente que possam ser assumidos, ou aprendidos, por todos os seres humanos, tanto no plano individual quanto no plano social.

O fato de considerar o caráter contínuo dessa tarefa demonstra que pensar a relação entre ética e educação implica problematizar o continuumm da açáo humana no horizonte do bem comum, ou melhor, na preservação e/ou transformação de uma esfera pública melhor possível para a existência humana. É por isso que se deve assumir como ponto de partida para qualquer debate sobre ética o seu caráter histórico:

A ética depara com uma experiência histórico-social no terreno da moral, ou seja, com uma série de práticas morais já em vigor e, partindo delas, procura determinar a essência da moral, ou seja, sua origem, suas condiçóes objetivas e subjetivas do ato moral, as fontes da avaliação moral, a natureza e a função dos juízos morais, os critérios de justificação destes juízos e o princípio que rege a mudança e a sucessão de diferentes sistemas morais. A ética é a teoria ou ciência do comportamento moral dos homens em sociedade. (VAZQUES, 2013, p. 23)

A proposição de que a experiência histórico-social seja uma condição para a reflexão da ética náo significa admitir seu caráter relativo e colocar em questáo sua pretensão de universalidade. Ao contrário, esse ponto 
de partida sugere considerar que as transformaçóes sociais, econômicas, políticas, culturais, tecnológicas, entre outras, também são critérios que orientam os rumos da reflexão ética diante de novos contextos.

É com base nessa perspectiva que o pensamento do filósofo alemão Hans Jonas (2006) tem instigado as teorias éticas contemporâneas a reverem seus pressupostos. Os novos problemas que surgiram a partir dos grandes impactos causados pelo avanço das transformaçóes técnicas e científicas que o autor denomina 'civilização tecnológica' demonstram que a especificidade dos impasses de nossa época exige que se traga ao centro da pauta questóes até então ignoradas, ou colocadas em segundo plano pelas geraçóes passadas. Isso porque nossos antepassados, devido às condiçôes limitadas da tecnologia em seu tempo, jamais poderiam ter esboçado tamanho prognóstico.

Trata-se de constatar que a civilização tecnológica também trouxe consigo o risco da continuidade da vida no planeta por causa do potencial destruidor que adquiriu o avanço da ciência e da tecnologia. Dessa forma, em sua obra $O$ princípio responsabilidade: ensaio de uma ética para civilização tecnológica (2006), Hans Jonas elabora uma contundente tentativa de refletir criticamente sobre a própria condição humana a partir do século $\mathrm{XX}$, a fim de lançar as bases para a fundamentação de uma nova ética para esse tempo. Obviamente que também sugere algumas proposiçôes sobre o que entenderia por uma educação pautada na sua ética da responsabilidade. Contudo, seu olhar filosófico não problematiza com profundidade os limites e possibilidades de uma filosofia da educação e, consequentemente, uma 'pedagogia da responsabilidade'.

Por isso, fez-se necessário adentrar nesse terreno a fim de encontrar elementos que dialoguem e subsidiem a problematização das consequências de uma educação que esteja de acordo com o princípio responsabilidade, isto é, com a sustentabilidade do planeta. De acordo com Gadotti (2002, p. 89), "o desenvolvimento sustentável tem um componente educativo formidável: a preservação do meio ambiente depende de uma consciência ecológica e a formação desta consciência depende da educação." Portanto, torna-se evidente que tematizar o problema da conscientização é uma questão central para essa perspectiva educacional e, nesse quesito, o pensamento político-pedagógico de Paulo Freire (1998) é de extrema relevância. O educador pernambucano ficou internacionalmente conhecido por ter debatido criteriosamente esse 
tema e ter propagado um pensamento pedagógico voltado para a conscientização, a fim de superar toda forma de opressão, domínio e violência, seja nas relaçôes humanas, ou entre os homens e a natureza.

Neste artigo, o desdobramento da reflexão se dá em três momentos: I) no primeiro, pretende-se compreender a crítica jonasiana à ética antropocêntrica, em especial à reflexão kantiana, e a formulação de um novo imperativo para os novos tempos; 2) no segundo momento, delimita-se a discussão em torno do conceito de 'heurística do temor', no qual Hans Jonas justifica a necessidade da previsão futura do mal prognóstico sobre o bom, de se assumir, em primeiro lugar, o risco iminente da tragédia antes de prospectar a busca coletiva da felicidade; 3) no terceiro momento, tece-se um diálogo sobre a heurística do temor e os fundamentos do pensamento político-pedagógico freiriano, a fim de estabelecer fronteiras de convergência entre esses dois autores no que se refere à busca de uma práxis educativa ética e responsável.

Por fim, procura-se interpretar a heurística do temor a partir da representação imagética de temas contemporâneos que ilustrem e demonstrem as consequências das irresponsabilidades em catástrofes - temor - sociais e ambientais, bem como de temas que revelem o caráter inventivo - heurístico - de iniciativas e atitudes locais e globais que traduzem o sentido da ética da responsabilidade defendida por Hans Jonas. Nessa perspectiva, a metodologia de problematização dos temas geradores presentes na abordagem do pensamento político-pedagógico freiriano são de extrema relevância, pois partem da compreensão crítica dos problemas locais e expandem dialeticamente para uma visão da conjuntura global da civilização tecnológica, a qual está alicerçada sobre as bases do modo de produção capitalista, cuja lógica predatória de expansão se pauta pela exploraçáo ilimitada do ser humano - e da natureza - pelo ser humano.

\section{Hans Jonas, a crítica ao caráter antropocêntrico da ética tradicional e a formulaçáo de um novo imperativo para uma ética do futuro}

O filósofo alemão Hans Jonas (1903-I993), de origem judaica, esteve no epicentro de vários acontecimentos que marcaram profundamente a 
história do século XX na Europa. Duas guerras mundiais e seus desdobramentos catastróficos no atentado à vida de inocentes; a aceleração da indústria armamentista e, consequentemente, a produção de armas nucleares com potencial de destruição em massa; o desenvolvimento do capitalismo e, ao mesmo tempo, suas sucessivas crises; a indústria do consumo e do descarte, que ameaça a existência de recursos naturais finitos e acumula desperdício em algumas regióes, enquanto em outras dissemina a miséria e a fome, entre outros. Inúmeros acontecimentos sem precedentes na história da humanidade constituem alguns dos profundos dramas desse século que mudou radicalmente os rumos de nossa civilização e trouxe outros elementos para uma nova reflexão sobre os problemas éticos.

A crítica jonasiana à insuficiência dos modelos éticos precedentes evidencia a afirmação de Vazquez (2013, p. 23) na introdução deste artigo: "A ética depara com uma experiência histórico-social [...] Ela é a teoria ou ciência do comportamento dos homens em sociedade." Ao serem estabelecidas as fronteiras dessa experiência histórico-social também se circunstanciam os limites para a reflexão sobre os fundamentos do agir humano em prol do bem comum. Assim, resta ao filósofo a tarefa de discernir e atualizar esse conceito de bem comum, e ao educador a tarefa de investigar sobre os meios de comunicar esse discernimento, traduzi-lo numa determinada prática e torná-lo vivencial, a fim de ampliar os horizontes da humanidade do ser humano, ou, como diria Paulo Freire, do 'ser mais' humano.

Ao observar de perto as grandes transformaçóes que ocorreram durante o século XX, Hans Jonas percebe a profundidade do impacto causado pela revolução tecnológica na transformação da própria natureza humana e conclui que a peculiaridade e a amplitude dessa mudança têm sérias consequências para o pensamento ético:

E, já que a ética tem a ver com o agir, a consequência lógica disso é que a natureza modificada do agir humano também impõe uma modificação na ética [...], pois a natureza qualitativamente nova de muitas de nossas açóes descortinou uma dimensão inteiramente nova do significado ético, não prevista nas perspectivas e nos cânones da ética tradicional. As novas faculdades que tenho em mente são, evidentemente, as da técnica moderna. Portanto, minha primeira questão é a respeito 
do modo como essa técnica afeta a natureza do nosso agir, até que ponto ela torna o agir sob seu domínio algo do que existiu ao longo dos tempos. (JONAS, 2006, p. 29)

O ponto de partida jonasiano para refletir sobre as características que distinguem a formulação de um pensamento ético para a civilização tecnológica em comparação com toda a história precedente é o fato de que a extensão da técnica moderna sobre a própria natureza do agir humano se torna infinitamente maior. Isso significa que o homo faber, isto é, a dimensão humana inventiva e criativa que se caracteriza pela capacidade de produzir artefatos, transformar a natureza, fabricar o meio artificial (tecnicamente) se sobrepóe ao homo sapiens (op. cit., p. 43), cuja principal finalidade estaria na capacidade racional e reflexiva de sua própria condição, do pensamento que busca a fundamentação do ser (ontologicidade).

Em outros termos, Hans Jonas chama a atenção para o fato de que o resultado da ação humana interventiva sobre o mundo, a esfera da técnica, se ampliou e influenciou consideravelmente a liberdade humana, conjugada à sua capacidade de decisão sobre o seu próprio destino. Desse modo, deve-se admitir que há uma substancial diferença entre a técnica pré-moderna e a técnica moderna. A primeira, pelo seu caráter isolado (local), lento e não intencional, não se caracterizou sobre a noção de um progresso continuado, de impacto contingencial e específico. Já a segunda se dá em escala global, sem definição de fronteiras específicas (em todas as dimensôes possíveis), um "impulso incerto alheio à vontade humana" (OLIVEIRA, 20I4, p. 95), uma finalidade em si, não a serviço da humanidade. Isso significa que as dimensóes, as extensões, os alcances e as consequências da técnica moderna reconfiguram a natureza da ação humana e colocam em questáo um novo problema. O poder da técnica demonstrou proporçôes imponentes que podem significar uma potencial ameaça à continuidade da existência de vida na terra, e por isso merece uma atenção especial do pensamento filosófico contemporâneo, principalmente no que se refere à ética.

Frente a esse novo cenário, Jonas retoma a reflexão sobre o imperativo ético kantiano e expóe os limites antropocêntricos de sua visão iluminista, restrita à universalização dos critérios racionais do agir moral circunstanciados no presente: 
O imperativo categórico de Kant dizia: "Aja de modo que tu também possas querer que tua máxima se torne lei geral.” Aqui, o "que tu possas" invocado é aquele da razão e de sua concordância consigo mesma: a partir da suposiçáo de uma sociedade de atores humanos (seres racionais em ação), a açáo deve existir de modo que possa ser concebida, sem contradição, como exercício geral da comunidade [...] Mas não existe nenhuma contradição em si na ideia de que a felicidade das geraçôes presentes e seguintes possa ser paga com a infelicidade ou mesmo com a não existência de geraçôes pósteras. (JONAS, 2006, p. 47)

A lógica do argumento kantiano sobre a fundamentação racional da moral e sua pretensão de universalidade não estaria comprometida se encarada no horizonte dos problemas do agir humano até a sua época. Entretanto, o novo elemento histórico que revelou o potencial destruidor da técnica moderna na contemporaneidade permite a Jonas identificar, no argumento de Kant, a ausência de um compromisso efetivo com a existência das geraçôes futuras. A generalização de um princípio para que se torne lei vale para toda a comunidade dos existentes no presente, mas desconsidera e, ao mesmo tempo, compromete a existência daqueles que ainda virão.

Portanto, a crítica jonasiana destaca a insuficiência do imperativo categórico kantiano - e de toda a ética tradicional, seja de caráter teocêntrico ou antropocêntrico (JONAS, 2006, p. 35) - diante dos problemas de nosso tempo, que em grande parte estão relacionados à supremacia do avanço da técnica: explosôes nucleares, efeitos massivos da radiação, poluição e aceleração do efeito estufa com aumento da temperatura global (ocasionando secas em algumas regióes e enchentes noutras), derretimento das calotas polares e aumento do nível dos oceanos, desmatamentos, monoculturas e contaminação da natureza com agrotóxicos etc. Inúmeros são os fatos que se acumulam e se intensificam na medida em que o progresso da técnica proclama sua marcha triunfal. O que está em jogo agora é o poder de autodestruição da humanidade e de toda forma de vida no planeta associado a um enorme sentimento de impotência, pois o conjunto das inovaçóes tecnológicas parecem uma totalidade independente do querer e do fazer humanos. (OLIVEIRA, 20IO, p. 40-4I) 
Assim, Jonas assume em sua reflexão a necessidade de incluir, na esfera do pensamento ético, o compromisso com a salvaguarda de possibilidade de vida sobre a terra a fim de garantir e assegurar as condiçóes de existência para as próximas gerações. Isso exige a superação do imediatismo egoísta em prol de uma reciprocidade voltada para a alteridade presente por uma responsabilidade altruísta com nossos descendentes ainda não existentes. Portanto, uma responsabilidade voltada para o futuro:

Um imperativo adequado ao novo tipo de agir humano e voltado para o novo tipo de sujeito atuante deveria ser mais ou menos assim: "Aja de modo que os efeitos da tua ação sejam compatíveis com a permanência de uma autêntica vida humana sobre a Terra"; ou, expresso negativamente: "Aja de modo a que os efeitos da tua ação não sejam destrutivos para a possibilidade futura de uma tal vida"; ou, simplesmente: "Não ponha em perigo as condições necessárias para a conservação indefinida da humanidade sobre a Terra"; ou, em uso novamente positivo: "Inclua na tua escolha presente a futura integridade do homem como um dos objetos do teu querer." (JONAS, 2006, 47-48)

Jonas é cuidadoso ao reinterpretar, ou adequar o imperativo kantiano diante dos riscos da civilização tecnológica. Para tornar inteligível esse novo imperativo, desdobra seu argumento em quatro máximas, dentre as quais, ao nosso ver, duas estão imbuídas da noção de positividade e duas da noção de negatividade. Positivamente (a primeira e a última), o filósofo incentiva e aconselha quanto à necessidade de práticas conscientes e que contribuam com a permanência da vida autêntica sobre o planeta, mas também exige que o exercício de nossa liberdade e do nosso querer ("inclua na tua escolha presente") tenha como objeto um conteúdo que ainda não existe: a integridade do homem futuro, o qual não poderá nos dar nada em troca. Já, negativamente, condena a permissividade irresponsável das açôes imediatistas que ignoram a iminência do perigo e do colapso previsível - já não é mais possível rifar o futuro nem pôr em perigo uma "conservação indefinida da vida”. $\mathrm{O}$ acaso náo pode ser a resposta ao comodismo, pois as previsóes alarmantes do atual estágio de nossa civilização não permitem 
que contemos com a sorte. Por isso, a necessidade de cautela e cuidado é uma constatação urgente, da qual não se pode mais esquivar.

Essa dupla noção (positiva e negativa) que identificamos no desdobramento das máximas da ética da responsabilidade jonasiana também está presente no conceito de 'heurística do temor ${ }^{\text {'1 }}$ que o autor utiliza para designar a prevalência do prognóstico negativo sobre o positivo em relaçáo ao que nos espera no futuro. Compreende-se essa responsabilidade também como a tentativa de se buscar os fundamentos para uma atualizaçáo da virtude da prudência, do cuidado e da responsabilidade para nossos tempos.

Por isso, neste segundo momento, procuraremos compreender melhor o significado da heurística do temor para captar seus princípios, a fim de problematizar a contribuição e a tradução de alguns elementos centrais do pensamento ético de Hans Jonas para a tematização dos fundamentos axiológicos da educação nos dias atuais.

\section{A heurística do temor}

Como foi afirmado anteriormente, Hans Jonas identifica na técnica moderna uma grande ameaça à vida no planeta. Não se trata de um pessimismo com o progresso a ponto de demonizar o avanço tecnológico com a pretensão saudosista de regredir historicamente à era pré-moderna, mas, sim, de reconhecer que a ação humana é marcada por uma certa ambiguidade, a qual, associada à magnitude interventiva dessa técnica (OLIVEIRA, 20I4, p. I28), revelará, mais cedo ou mais tarde, a face tenebrosa de tal condição. Admite-se, porém, que a vulnerabilidade deixa de ser apenas uma hipótese quimérica e se configura como uma possibilidade real, passível de ser conhecida.

O conhecimento dessa 'previsão', de acordo com Jonas, é denominado 'futurologia comparativa', ou 'ciência da previsão hipotética'. Ela serve para diagnosticar o que se deve esperar, o que se deve incentivar e o que se deve evitar (JONAS, 2006, p. 70). Portanto, é uma ética a ser fundamentada a médio e longo prazo. Todavia, ainda resta a questão: como seria possível mensurar o conteúdo histórico do futuro? Assim o filósofo alemão esclarece essa dúvida: 
Precisamos da ameaça à imagem humana - e de tipos de ameaça bem determinados - para, com o pavor gerado, afirmarmos uma imagem humana autêntica. Enquanto o perigo for desconhecido não se saberá o que há para se proteger e por que devemos fazê-lo, por isso, contrariando toda lógica e método, o saber se origina daquilo contra o que devemos nos proteger [...]. O que nós não queremos, sabemos muito antes do que aquilo que queremos. Por isso, para investigar o que realmente valorizamos, a filosofia da moral tem de consultar o nosso medo antes do nosso desejo. (JONAS, 2006, p. 70-7I)

Ao assumir a ambiguidade da ação humana, que implica na ambiguidade e contradição dos nossos próprios desejos, associadas ao potencial destruidor da técnica, se deduz logicamente que o perigo é uma possibilidade mais que provável, mas também previsível. Ora, isso implica admitir que entre um bem indefinido do 'tudo' (uma vida feliz no futuro) e o risco aterrorizante do 'nada' (a aniquilação da vida), a segunda opção se destaca e tem primazia, pois deve ser evitada a qualquer custo para que continue havendo condição de possibilidade da primeira. De acordo com Jonas, o mal prognóstico tem a primazia sobre o bom e, na medida em que é esboçado, compreendido e aceito pela geração presente, deve incidir sobre suas tomadas de decisão em vista do compromisso com as futuras geraçóes. Por isso, assume o pressuposto de que a consulta àquilo que se teme deve anteceder à vontade de consumação dos desejos. O querer é cambaleante, vulnerável, oscila entre as possibilidades e variedades de boas opçóes disponíveis; já o não-querer é mais objetivo, definido, delineia automaticamente a esfera preventiva do saber prático sobre o que deve ser evitado.

Por essa razão, Hans Jonas cunha a expressão "heurística do temor"2 (id.ib.) a fim de dar sentido ao argumento central de sua ética da responsabilidade para conter os efeitos da civilização tecnológica. A heurística do temor é uma noção emblemática que precisa ser bem compreendida para expressar o sentido pedagógico da prudência nas relaçóes entre essa ética da responsabilidade e a educação. Como já explicitado, o temor - ao contrário do medo que caracteriza a paralizaçáo e a imobilidade - representa um sentimento de impacto, espanto, perplexidade, sentido que subjaz nas expressóes utilizadas por Aristóteles para designar aquilo que deu origem 
ao pensamento filosófico ${ }^{3}$. A função desse temor seria despertar a perplexidade cognitiva e prática (moral) frente às intempéries futuras de modo que se possa esboçar no presente um quadro de moderação coletiva para prevenir, com responsabilidade, o mal que se quer evitar e, ao mesmo tempo, garantir a possibilidade da permanência da vida. Como destaca Sganzerla (20I2, p. 222):

Trata-se de uma forma de prudência no agir despertado pela preferência do mal prognóstico, de modo que se possa antecipar ou mesmo impedir a ação e a necessidade da reparação do dano, isto é, diante de prognósticos incertos e da ameaça da continuidade da vida autêntica no futuro, a cautela, a prevenção, e a prudência assumem o papel de guia das açóes humanas.

Ou como declara o autor no fim da obra $O$ princípio responsabilida$d e:$ "[...] o medo que faz parte da responsabilidade não é aquele que nos aconselha a não agir, mas aquele que nos convida a agir." (JONAS, 2006, p. 35I)

Por sua vez, a palavra heurística vem do grego eurisko, que significa descoberta, achado, pesquisa ou arte de pesquisar (ABBAGNANO, 2007, p. 499), daí a expressão eureka, que a tradição filosófica atribui ao sábio grego Arquimedes, quando este, ao banhar-se numa banheira, percebeu o deslocamento da água e presumiu que esse ato representava o mesmo volume ocupado pelo seu corpo. Nesse sentido, o termo heurística porta a noção de uma descoberta súbita, uma intuição imediata, um conhecimento que desperta de um interesse espontâneo e curioso de quem está constantemente motivado em desvendar aquilo que o cerca e aprender com e a partir da obviedade. Com a heurística deixa-se de se ter uma posição passiva diante da obviedade, mas assume-se o risco como condição de aprendizado. De acordo com Oliveira (20I4, p. I30):

A ameaça, portanto, ganha um caráter heurístico, pois o saber sobre o risco geraria, segundo Jonas, pelo caráter do "conhecimento do malum" (PR, p. 7I) como uma potencialidade e uma possibilidade, a alteração das atitudes e comportamentos no presente. Trata-se de uma probabilística negativa que faz 
derivar o princípio ou inventa (eurisko) a partir do que deve ser evitado, preferindo a consulta aos temores humanos mais do que aos desejos, aspiraçóes e esperanças.

Isso permite admitir que o conhecimento do malum (de um mal prognóstico sobre o futuro) deve prevalecer sobre as conjecturas sobre o bonum (as esperanças de um mundo melhor no devir histórico). Essa prevalência se ancora numa dedução hipotética presumível e tem o papel de estimular a inspiração, a comoção e o esclarecimento da reflexão e do agir humanos na perspectiva da prevenção cuidadosa universal, de uma cautela partilhada coletivamente, cujo único propósito é a preservação da vida. Sobre esse aspecto Jonas (2006, p. 72) continua a elucidação:

Esse é o caso da "ética do futuro" que estamos buscando: o que deve ser temido ainda não foi experimentado e talvez não possua analogias na experiência do passado e do presente. Portanto, o malum imaginado deve assumir aqui o papel do malum experimentado. Como essa representação não acontece automaticamente, ela deve ser produzida intencionalmente: portanto, obter uma projeção desse futuro torna-se um primeiro dever, por assim dizer introdutório, da ética que buscamos.

A reflexão aponta para uma questão muito séria quando se trata de justificar a arquitetura das bases viáveis dessa ética do futuro. Como é possível temer algo que não foi ou ainda não é palpável, ou que sequer tenha passado pelo crivo da experiência humana? Como encontrar fatos análogos em nossa recente historiografia para justificar a radicalidade dessa tomada de posição? Jonas responde a essas perguntas ponderando com os argumentos apresentados: este mal imaginado deve ser assumido como se fosse experimentado por antecipação. Isso implica que haja uma 'produçáo' intencional em forma de representação, projeçáo, tarefa essa inicial em toda ética da responsabilidade. Nesse sentido, o "temor tem caráter pedagógico, enquanto o medo é paralisante. $\mathrm{O}$ temor mobiliza, enquanto o medo imobiliza." (SGANZERLA, 20I2, p. 224)

$\mathrm{O}$ argumento decisivo para refrear os rumos destruidores do planeta é a prospecção drástica desse cenário. A heurística do temor pautada no 
reconhecimento de uma catástrofe que ainda não se consumou, mas que se anuncia em vias de fato, pode ser um recurso cognitivo impactante para despertar a consciência dos indivíduos para reavaliar os fins de sua conduta.

Com isso, damos continuidade à nossa reflexão, a fim de que possamos articular essa dupla noção (positiva e negativa) que acabamos de explicitar sobre a heurística do temor em Hans Jonas em consonância com o desdobramento das suas máximas para a formulação de proposiçóes reflexivas com base nos imperativos da ética da responsabilidade e suas possíveis interlocuções com o campo educacional. Primeiro, procuramos fazer uma incursão sobre a compreensão jonasiana de educação e, posteriormente, articulamos com um aporte ao pensamento político-pedagógico freiriano, a fim de problematizar os pressupostos metodológicos de uma pedagogia para a ética da responsabilidade, uma pedagogia da terra, ou uma 'ecopedagogia'.

\section{Educação e ética da responsabilidade: aportes freirianos para uma reflexáo ecopedagógica sobre a heurística do temor}

A reciprocidade entre educação e ética se fundamenta na efetivação do inacabamento humano. Um inacabamento consciente, em processo de projeção constante de suas potencialidades conforme as possibilidades históricas, mas também efetivação contingencial de si no mundo, que também não está acabado. Ora, se o mundo está em processo de construção, a história também se faz continuamente, o que implica decisões a serem tomadas, rupturas a serem feitas, posiçóes a serem assumidas e visóes a serem projetadas. Como diz Paulo Freire (2006, p. 48), ao se referir à simbiose entre ética e educação, "nenhuma teoria da transformação político-social do mundo me comove, se quer, se não se parte de uma compreensão do homem e da mulher enquanto seres fazedores da história e por ela feitos, seres de decisão, de ruptura, da opção." Quer dizer, o futuro não depende de uma entidade supranatural, ou das forças do acaso, o futuro será resultado das opçóes e escolhas que os seres humanos realizarem na atualidade. Se, de acordo com Jonas, a civilização tecnológica forjou as bases para o 
fim da vida, também poderá decidir forjar o caminho da preservação e do cuidado com o planeta.

E é por isso que se identifica uma profunda fecundidade de sentido entre a proposta jonasiana de uma ética do futuro e a educaçâo diante dos problemas fundamentais do nosso tempo. De acordo com Jonas, o atual estágio de nossa civilização tecnológica nos impóe um paradoxo sem precedentes na história, o qual exige uma ruptura radical com um determinado modelo de desenvolvimento, que por sua vez impóe tomadas de decisão sobre o que deve ser evitado, mas também opções que se configurem em atitudes responsáveis e coerentes com a preservação da natureza, bem como das condiçóes de possibilidade para a continuidade da existência humana nesta terra.

Numa das poucas passagens em que Hans Jonas comenta a questão da educação, em sua obra $O$ princípio responsabilidade, ele o faz para circunstanciar o que há de comum e unificador entre dois polos identificados como modelos da responsabilidade humana: a responsabilidade parental e a responsabilidade política. A primeira se refere ao arquétipo do cuidado não recíproco dos pais, que assumem uma relação imediata, singular e natural no que se refere à responsabilidade com os filhos: "seu objeto é a criança como um todo e todas as suas possibilidades [...] acrescenta-se tudo que entendemos por 'educação': habilidades, comportamentos, relaçôes, caráter, conhecimento, os quais devem ser supervisionados durante o desenvolvimento da criança." (JONAS, 2006, p. I80) A segunda trata do cuidado assumido em nome de uma coletividade, da res pública, o que leva à disposição voluntária do indivíduo de representar interesses mais gerais, mediatos (precisam de mediação institucional de interesses plurais, jurídica, legal etc), e, por isso, também adquire o poder para influenciar a concepção e preservação dos deveres públicos. Assim comenta Jonas (op. cit., p. 80):

Contudo, essas duas responsabilidades tão divergentes, uma representando a maior das singularidades e a outra a mais ampla generalidade, interpenetram-se de forma notável. Primeiro, quanto ao objeto: a educação da criança inclui a introdução no mundo dos homens, começando com a linguagem e seguindo com a transmissão de todo o código de crenças e normas sociais, 
cuja apropriação permite que o indivíduo se torne da sociedade mais ampla. O privado se abre para o público e incorpora-o como parte integral do Ser da pessoa. Em outras palavras, o "cidadáo" é um objetivo imanente da educação, e assim parte da responsabilidade dos pais, náo só por causa da imposição do Estado. Por outro lado, assim como os pais educam os filhos "para o Estado" (e para muitas outras coisas), o estado assume para si a educação das crianças [...] Ou seja, o Estado não quer apenas receber os cidadãos já formados, quer participar da sua formação.

De acordo com essa polarização arquetípica sobre os agentes da responsabilidade no âmbito privado e público, os pais e os políticos ou pessoas públicas ganham certa centralidade no que se refere ao cumprimento dessa ética do futuro. Isso implica que se reconheça os educadores e a ação educativa como parte integrante de um compromisso público e dever do Estado no ato de educar a populaçáo, de ampliar cada vez mais os horizontes da prática da responsabilidade na esfera pública, do exercício da cidadania. Daí que a educação seja também uma ação política e crítica, cujo principal valor reside na formação humana para além da adaptação ao status quo, assim como de concepçóes que defendem uma suposta neutralidade no processo educativo.

A compreensão de uma educação voltada para a vivência ética da responsabilidade na esfera pública deve estar de acordo com a própria abrangência da noção de política pública, como diz Jonas (op. cit., p. 44): "importa aqui o ator coletivo e o ato coletivo [...]. Nunca a política pública teve de lidar com questóes de tal abrangência e que demandassem projeçôes temporais tão longas. De fato, a natureza modificada do agir humano altera a natureza fundamental da política.”

Obviamente que, se houve uma modificação na natureza do agir humano, também deverá acontecer uma mudança radical no que se refere à concepção da natureza da política. A ação na polis não pode mais ser circunscrita dentro dos limites geográficos da cidade ou Estado, mas agora, diante de uma ameaça aterradora, a polis é o mundo. Do mesmo modo, a cidadania necessita de uma ampliação das suas fronteiras, para além de uma delimitação às relaçóes humanas, mas precisa considerar aquilo que 
é 'suporte' para a vida em geral, condição para a existência humana. É imprescindível admitir que educação e política passam a ser dois lados da mesma moeda.

Nesse sentido, Paulo Freire (200I) demonstrou insistentemente que a educação é um ato político, ou melhor, não há como conceber a ação educativa basicamente como mecanicista, tecnicista ou neutra. $\mathrm{O}$ ato educativo sempre implica numa determinada visão de mundo a ser assumida a favor de uma causa, de alguém, ou imbuída de um motivo que, por sua vez, se volta contra alguém que defende uma causa e que também tem seus motivos.

Para Freire, a educação libertadora, também compreendida como ação político-pedagógica, pressupóe a superação da opressão num duplo sentido: no primeiro, a expulsão da visáo dos opressores hospedada na consciência dos oprimidos; no segundo, a expulsão do opressor que está fora, que exerce a dominação de classe, em favor da manutenção da realidade em favor de seus próprios interesses. A pedagogia bancária, instrumento de dominação da opressão, é antidialógica, pois é manipuladora, divisora, visa a conquista e torna-se invasiva culturalmente. Basicamente, essa pedagogia separa os seres humanos do mundo, apartaos da realidade e fragmenta sua visão de mundo. Para essa pedagogia, tanto o ser humano quanto o mundo e a natureza não passam de objetos a serem usados e descartados. Para superar essa condição, Freire (I998) sugere uma pedagogia da ação dialógica cujos pressupostos são a 'colaboração', a união, a organização e a síntese cultural que têm como objetivo a integraçáo dos seres humanos ao mundo vivido. Compreende-os como sujeitos e considera a natureza uma extensão da realidade humana, a qual deve ser cuidada e preservada.

O educador pernambucano também foi um árduo defensor da preservação da vida e das condiçôes para que houvesse essa vida. Nos últimos anos de sua existência, inclui em sua reflexão pedagógica a temática da ecologia como tema central, pois considera que a educação não pode negligenciar os problemas globais da civilização tecnológica, que se tornaram temas centrais dos seres humanos e do planeta Terra como seres oprimidos:

[...] urge que assumamos o dever de lutar pelos princípios éticos mais fundamentais como respeito à vida dos seres huma- 
nos, à vida dos outros animais, à vida dos pássaros, à vida dos rios e das florestas. Não creio na amorosidade entre mulheres e homens, entre os seres humanos, se não nos tornamos capazes de amar o mundo. A ecologia ganha uma importância fundamental neste fim de século. Ela tem de estar presente em qualquer prática educativa de caráter radical, crítico e libertador. (FREIRE, 2000, p. 66-67)

A amorosidade humana só faz sentido se fecundar no mundo, na relação com os animais, as plantas, enfim, todos os seres vivos. Uma educação radical, que procura ir às raízes (do latim, radix) dos problemas da época contemporânea, deve tomar a temática da ecologia como assunto central, o qual diz respeito a todos os seres humanos. Todavia, é importante destacar que a relação que Freire (200I, p. 44) estabelece entre educação libertadora e o cultivo da dimensão da responsabilidade pressupóe que "não há educação para a libertação, cujos sujeitos atuem coerentemente, que não seja imbuída de forte senso de responsabilidade." Portanto, assim como em Hans Jonas, no pensamento freiriano educação, política e responsabilidade também se entrelaçam.

Dito isso, percebe-se que a educação libertadora, de acordo com os pressupostos da ética da responsabilidade, tem a finalidade de desmascarar toda e qualquer forma de ideologia que propague e cultive a competitividade, a meritocracia e a reciprocidade monetária, cujos princípios estão de acordo com interesses egoístas, privados, predatórios. Essa lógica impede a assunção de uma visão coletiva, pública e cidadã da responsabilidade a médio e longo prazo, baseada na solidariedade, no cuidado com a natureza e na reciprocidade com a vida em geral acima de tudo. A respeito dessas possíveis relaçóes entre a ética jonasiana e a educação, comenta o filósofo Lourenço Zancanaro (20II, p. I):

No campo da educação, a teoria da responsabilidade ajudará a levantar questóes que poderão contribuir para a filosofia da educação. Não obstante, não poderá referir-se à escola como única responsável pelo sucesso ou pelo fracasso da vida em sociedade. A educação perfaz a totalidade das ações, desde aquelas veiculadas pelos meios de comunicação, das açóes públicas 
dos legisladores, do respeito intersubjetivo dentro do espaço público e da responsabilidade paterna como arquétipo de toda responsabilidade. Posto que a tarefa da educação no seu sentido amplo é dar uma formação global de conhecimentos que auxiliam a gestão da vida no mundo, a ética da responsabilidade poderá ser um bom instrumento na valorização da vida, do meio ambiente e de tudo que deve existir.

Equivale a dizer que é preciso conceber a sociedade como uma comunidade político-educativa e construir um espaço público em que a escola se apresente como dinamizadora da responsabilidade nos mais variados campos de atuação: na ciência, na tecnologia, nos esportes, nas artes, nas relaçóes de produçáo, ou nas relaçóes de lazer, entre os quais os egressos estarão presentes, contando que a grande totalidade deles também serâo pais e/ou futuros agentes/políticos - homens públicos. Sobre isso, Dickmann (20I7, p. 66) sugere que as questóes socioambientais sejam incluídas criticamente nos currículos de modo "multi, inter e transdisciplinar, garantindo a transversalidade do tratamento do tema em todas as disciplinas e em todos os níveis de ensino como indicam os documentos oficiais e as Diretrizes Curriculares para a Educação Ambiental."

O potencial crítico e conscientizador do pensamento político-pedagógico freiriano pode servir de base ao método conjectural para traduzir a ética da responsabilidade no campo educacional e problematizar elementos que possam contribuir para a reprodução imagética do temor, ao mesmo passo que possa explorar as dimensóes heurísticas do mesmo, instigando a racionalidade intuitiva a compreender e buscar alternativas disponíveis no presente, mas também a criar formas de apontar saídas aos impasses futuros. Como aquilo afirmado anteriormente, essa imagem "deve ser produzida intencionalmente: portanto, obter uma projeção desse futuro torna-se um primeiro dever, por assim dizer introdutório, da ética que buscamos." (JONAS, 2006, p. 72) A tarefa da educação problematizadora para uma ética da responsabilidade, nesse quesito introdutório de projeção, precisa considerar e tematizar - na perspectiva freiriana da investigaçáo dos temas geradores - os elementos que denunciam os perigos de nossa época no âmbito planetário. 
Esse exercício pode partir do pressuposto de que há uma relação entre local e global, a fim de que haja um alargamento da compreensão da vida coletiva, pública, bem como de sua compreensão para além do presente. Do ponto de vista do temor, náo se pode deixar de confrontar dialeticamente os problemas locais em sua relação com os problemas globais. $\mathrm{O}$ exercício da contextualização do conhecimento necessita da investigação rigorosa dos temas geradores que ameaçam a vida em geral como o aumento crescente da poluição ambiental nas grandes economias consumistas; a consideração dos cientistas sobre a elevação da temperatura mundial nesse próximo século, o que impacta no derretimento das calotas polares; o aumento da água dos oceanos; o alagamento das povoaçóes costeiras; o impacto climático sobre a produção de alimentos; o processo de desertificação de regiôes produtivas; a possibilidade de escassez de água potável; a exploração predatória dos recursos energéticos naturais finitos (metais, madeiras nativas, petróleo), o desenvolvimento de armas de extermínio em massa; os testes com bombas nucleares.

Os sinais presentes nos eventos que vêm acontecendo nas últimas décadas apontam seriamente para consequências catastróficas de proporçôes universais, incontroláveis e irreversíveis. E, por isso, a projeção imagética em escala crescente desses problemas constitui um dever da ação educativa política comprometida com a ética da responsabilidade. Do ponto de vista heurístico, compreendido como espanto inventivo, em criatividade intuitiva e descoberta inovadora, que é capaz de buscar alternativas originais e responsáveis diante dos problemas de nosso tempo, não podem ser deixados de lado temas geradores como: a economia solidária e o consumo consciente; a agroecologia como ciência do cuidado com a natureza, que busca a diversificação da produção de acordo com as características e biomas regionais; as pesquisas e desenvolvimento de tecnologias que promovem a utilização de fontes renováveis de energia (eólica, biodiesel, solar); o transporte público de qualidade como alternativa à concentração de automóveis nas metrópoles; a construção e utilização de ciclovias; a coleta seletiva de materiais recicláveis e a transformação de resíduos orgânicos para racionalização de aterros sanitários; a redução do impacto da emissão de resíduos sólidos que poluem lençóis freáticos, nascentes e rios.

São, portanto, inúmeras as opçóes de caráter inventivo que acenam para a responsabilidade e o cuidado público com a natureza no intuito de 
assegurar as condiçóes de vida das futuras geraçóes. Não faltam soluçóes criativas, tanto no plano tecnológico quanto no plano político e societário, para inspirar novos comportamentos - o que faltam ainda são decisôes a serem tomadas que impliquem rupturas abruptas a serem assumidas coletivamente. A ação educativa problematizadora, ao considerar esses fenômenos, não pode avaliá-los meramente do ponto de vista descritivo, analítico e isolado. Todos estáo interconectados e exigem uma abordagem interdisciplinar, crítica, denunciante, qualificada e criteriosa, mas também corajosa, prospectiva e anunciante.

E é justamente nesse ponto que se inscreve o papel da educação problematizadora freiriana para essa ética da responsabilidade com o futuro. A contribuição da pedagogia dialógica vem ao encontro dos apelos da heurística do temor, cuja finalidade é a prática da ética da responsabilidade. A investigação temática e a problematização e contextualização dos temas geradores podem assumir essa tarefa de produção intencional da representaçáo dessa imagem do temor que ainda náo foi experimentado, de modo que se traduzam em aspectos pedagógicos seus reais propósitos para prospectar conjunturas, fomentar decisôes e rupturas e estimular que a consciência da responsabilidade seja partilhada globalmente. Essa representação pode partir de exemplos de fatos e eventos acontecidos que prefiguram a prospecçáo deste malum em escala global, como também de iniciativas, atitudes e compromissos que sinalizam os princípios heurísticos do cuidado e da prevençáo com o futuro do planeta.

A conscientização com relação à ética da responsabilidade conflui para aquilo que Gadotti (2002) chama de ecopedagogia, uma pedagogia fundamentada no pensamento freiriano, cuja finalidade seja a prática de uma educação libertadora e sustentável. A ecopedagogia visa o exercício consciente de práticas sustentáveis, que zelam pelo cuidado com a vida em geral no planeta, de modo que a cidadania ambiental local também se torne uma cidadania planetária, que se arvora numa consciência e numa solidariedade que também são planetárias:

Ela só tem sentido [a ecopedagogia] como projeto alternativo global onde a preocupação não está apenas na preservação da natureza (Ecologia Natural) ou no impacto das sociedades humana sobre os ambientes naturais (Ecologia Social), mas 
num novo modelo de civilização sustentável do pondo de vista ecológico (Ecologia Integral), que implica uma mudança nas estruturas econômicas, sociais e culturais. (GADOTTI, 2002, p. 94)

A noção implícita ao conceito de cidadania planetária está em profunda sintonia com a ética da responsabilidade jonasiana. $\mathrm{O}$ cidadão planetário possui uma consciência universal: inclui no horizonte da sua ética não só os seres humanos no presente, mas considera as condiçóes para a preservação da vida como um todo, inclusive no futuro. Por isso, se assenta na noção de ecologia integral, cuja finalidade é a busca de um equilíbrio dinâmico e harmônico entre ser humano e natureza, concebendo a complexidade da realidade e como tudo está em conexão.

\section{Consideraçóes finais}

Pode-se concluir que o princípio responsabilidade na fundamentaçáo de uma ética para a civilização tecnológica exige que se promova a ascensão de uma consciência ingênua, imediatista e individualista para uma consciência crítica, a longo prazo e coletiva. Esse processo de conscientização é uma tarefa política da educação libertadora, a qual fornece as bases metodológicas para problematizar e sistematizar a compreensão dos problemas centrais de nossa época. A compreensão de uma situação-limite global pressupóe temas geradores cuja inspiraçáo seja o temor, o qual sugere o despertar para uma consciência planetária e responsável. A prospecçáo de alternativas para esse impasse sugere a análise crítica de temas geradores que inspirem a prática da responsabilidade, o exercício heurístico, inventivo e criativo de saídas 'ineditamente-viáveis', ainda não experimentadas, mas que são possíveis se houver uma opção ecopedagógica coletiva, ampla e cidadã.

Assim, a filosofia da educação implícita na concepção político-pedagógica libertadora, ao mesmo tempo em que exerce compromisso de promover as conjecturas desta imagem do temor, também se preocupa em investigar heuristicamente a promoçáo de atitudes no presente, as quais revelam essa preocupação com a prudência e zelo com o futuro das próximas geraçôes. 


\section{Notas}

1 Utilizamos a expressão heurística do temor neste texto contrariando a tradução do termo que foi utilizada na obra consultada, que preferiu heurística do medo. Nossa posição se fundamenta na interpretação do estudioso do pensamento jonasiano, professor Jelson Oliveira, a qual explicitaremos no decorrer do texto. (Cf. OLIVEIRA, Jelson. Compreender Hans Jonas. Petrópolis, RJ: Vozes, 2014)

2 Para uma melhor hermenêutica do termo alemão Heuristik der Furcht, utilizado por Hans Jonas em sua obra $O$ princípio responsabilidade (2006), os filósofos Jelson Oliveira e Anor Zganserla comentam respectivamente: "Preferimos aqui a tradução do conceito Heuristic der Furcht, por heurítica do temor, diferentemente do que propuseram Marjiane Lisboa e Luz Barros Montes na tradução para o português de O princípio Responsabilidade (2006). A nosso ver, a palavra medo tem uma posição negativa, por transmitir a ideia náo de um sentimento passivo, mas de um receio fundado, de um medo acompanhado pela força de respeito frente à força do mal iminente, de escrúpulo e zelo que promovem a precaução." (CF. OLIVEIRA, 20I4, p. I24); "Mesmo que a palavra Angst (alemão) e fear (inglês) "permitam" a tradução por medo ou temor, nessa pesquisa assumimos a posição que parece ser mais coerente da apropriada para a heurística jonasiana, por isso da opção pela utilizaçáo do termo temor, por considerar que a palavra medo não carrega em si uma qualidade heurística." (Cf. SGANZERLA, 20I2, p. 223)

3 "É por força de seu maravilhamento que os seres humanos começam agora a filosofar e, originalmente, começaram a filosofar; maravilhando-se primeiramente ante perplexidades óbvias e, em seguida, por um progresso gradual, levantando questôes também acerca das grandes matérias, por exemplo, a respeito das mutaçôes da lua e do sol, a respeito dos astros e a respeito da origem do universo. Ora, aquele que se maravilha e está perplexo sente que é ignorante [...] portanto, se foi para escapar à ignorância que se estudou filosofia, é evidente que se buscou a ciência por amor ao conhecimento." (ARISTÓTELES, 20I2, p. 46)

\section{Referências}

ABBAGNANO, Nicola. Dicionário de Filosofia. $5^{\text {a }}$ ed. São Paulo: Martins Fontes, 2007.

ARISTÓTELES. Metafísica. 2 ed. Trad. Edson Bini. São Paulo: EDIPRO, 2012.

DICKMANN, Ivo. Pedagogia da (in)disciplina ambiental: desafios políticopedagógicos na formação de educadores ambientais no ensino superior. In: Rev. Eletrônica Mestr. Educ. Ambient. Rio Grande, Edição especial XVI Encontro Paranaense de Educação Ambiental, set. 2017, p. 55-70.

FREIRE, Paulo. Pedagogia do oprimido. I8. ed. Rio de Janeiro: Paz e Terra, I988. UNESP, 2000. Pedagogia da indignação: cartas pedagógicas e outros escritos. São Paulo: . Política e educação: Ensaios. 5. ed. São Paulo: Cortez, 200 I. 
GADOTTI, Moacir. Pedagogia da Terra: Ecopedagogia e Educação Sustentável. In: TORRES, Carlos A (Org.). Paulo Freire y la agenda de la educación latinoamericana en el siglo XXI. Buenos Aires: CLACSO, 2002, p. 8I-I32)

HOEPERS, Ricardo. O princípio da responsabilidade de Hans Jonas e o imperativo de uma ética para a educação (Dissertação de mestrado). Programa de Pós-Graduação em Educação da Pontifícia Universidade Católica do Paraná. Curitiba: PUCPR, 2005.

JONAS, Hans. O princípio responsabilidade: ensaio de uma ética para a civilização tecnológica. Rio de Janeiro: Contraponto; Ed. PUC-Rio, 2006.

OLIVEIRA, Jelson. Compreender Hans Jonas. Petrópolis, RJ: Vozes, 2014.

OLIVEIRA. Manfredo A. (org.). Correntes fundamentais da ética contemporânea. 5 ed. Petrópolis, RJ: Vozes, 2014.

. Ética, direito e democracia. São Paulo: Paulus, 20 Io.

SGANZERLA, Anor. Natureza e responsabilidade: Hans Jonas e a biologização do ser moral (Tese de Doutorado). Programa de Pós-graduação em Filosofia e Metodologia das Ciências. Universidade Federal de S. Carlos. São Carlos, SP: UFSCar, 2012.

VÁZQUEZ, Adolfo Sanchez. Ética. Trad. João Dell'Anna. 35 ed. Rio de Janeiro: Civilização Brasileira, 2013.

ZANCANARO, Lourenço. Por uma ética do cuidado e da responsabilidade. In: Revista do IHU online, agosto de 20I I. Disponível em: <http://www.ihuonline.unisinos.br/ index.php?option=com_content\&view $=$ article $\& i d=4032 \&$ secao $=37 \mathrm{I}>$. Acesso em $2 \mathrm{I}$ de julho de 2015 .

Recebido em I8 mar. 2018 / Aprovado em 8 mai. 2019 Para referenciar este texto:

PEROZA, J. O princípio responsabilidade e a educação: aportes freirianos para uma compreensão ecopedagógica da heurística do temor em Hans Jonas. EccoS - Revista Científica, São Paulo, n. 50, e8485, jul./set. 2019. Disponível em: https://doi. org/I0.5585/EccoS.n50.8485. 